УДК 629.47.004.18

УДОСКОНАЛЕННЯ РЕМОНТУ РАМ ВІЗКІВ ЕЛЕКТРОВОЗА ВЛ8

Магістрант О.С. Машкін

СОВЕРШЕНСТВОВАНИЕ РЕМОНТА РАМ ТЕЛЕЖЕК ЭЛЕКТРОВОЗА ВЛЯ

Магистрант А.С. Машкин

IMPROVING REPAIR ELECTRIC LOCOMOTIVE BOGIE FRAMES VL8

\title{
UndergraduateA.S. Mashkin
}

У статті проведено аналіз існуючих методів та способів діагностування основних несучих елементів електровоза, визначено основні показники, які можуть бути використані для вибору діагностичних параметрів.

Проведено аналіз існуючих систем та пристроїв для визначення залишкового ресурсу рам візків електровозів ВЛ8, запропонована технологія діагностування, яка може бути використана $в$ локомотивному депо, та наведено принцип роботи діагностичного комплексу.

Ключові слова: електровоз, рама візка, надійність, термін служби, діагностування, залишковий ресурс, метод розрахунку, імовірність, неруйнівний контроль, кінцеві елементи, твердотільна модель, діагностичний комплекс. 
В статье проведен анализ существующих методов и способов диагностирования основных несущих элементов электровоза, определены основные показатели, которые могут быть использованы для выбора диагностических параметров.

Проведен анализ существуюших систем и устройств для определения остаточного ресурса рам тележек электровозов ВЛ8, предложена технология диагностирования, которая может быть использована в локомотивном депо, и приведен принщип работы диагностического комплекса.

Ключевые слова: электровоз, рама тележки, надежность, срок службы, диагностирование, остаточный ресурс, метод расчета, вероятность, неразрушающий контроль, конечніе элементы, твердотельная модель, диагностический комплекс.

In Article wires dannoy analysis of existing methods and sposobovdyahnostyrovanyyanesuschyh major elements эlektrovoza, opredelenbl Basic Indicator, kotorblemogutbbltyspolzovanbl for Choice diagnostically parameters.

The analysis of existing methods of determining the residual life of the carrier konstruktsiy locomotives, the most widely used of which it is the parametric method based on measuring the strength of the material koertsitativnoy bearing structure. Such measurements should be carried out throughout the lifetime of the frame telizhki.

Rozglyanuta procedure of calculation by finite element method bogie frame. The calculations obtained diagrams of stress and deformatsiy separate areas of the frame that allowed to identify the most tense areas of the frame and place for the installation of sensors telizhki during diagnosis.

Conducted analysis of existing systems and devices for final resource definitions frames telezhekэlektrovozov VL8, predlozhennaya technology dyahnostyrovanyya, kotoraja Can buttyspolzovana a locomotive depot and pryvedenu principle work diagnostically complex.

Keywords: locomotive, bogie frame, reliability, service life, diagnosis, residual life, the method of calculating the probability, nondestructive testing, finite element model of solid-state, diagnostic equipment.

Вступ. Актуальність роботи визначається гостротою проблеми оновлення рухомого складу на залізницях країни. Аналіз роботи локомотивних депо показує, що середні витрати на локомотивне господарство складають $31,6 \%$ від загальних витрат на підприємствах, які $\epsilon$ найбільшою частиною серед інших господарств залізничного транспорту. У зв'язку із зростанням ціни вартості запасних частин та витратних матеріалів підвищуються витрати на утримання локомотивів. Скорочення частки цих витрат $\epsilon$ значним резервом підвищення ефективності локомотивної тяги залізничного транспорту $[5,6]$.

Постановка проблеми. Відповідно до Програми оновлення рухомого складу, кількість локомотивів інвентарного парку Укрзалізниці, що вичерпали встановлений заводами-виробниками нормативний термін експлуатації, підходить до критичної точки. Зношування електровозів досягло $90 \%$, а їх середній вік - 36 років. Вже вичерпали свій ресурс локомотиви серій ВЛ8, ВЛ60, ВЛ80 і ЧС2. Зокрема, у найгіршому стані в цих електровозах перебувають рами візків, які $\epsilon$ основним несучим елементом візка і впливають на безпеку руху [1].

Тому розроблення та впровадження заходів щодо підвищення надійності, енергоефективності та продовження терміну служби локомотивів, а саме рам візків електровозів i удосконалення їх утримання має для залізничного транспортуособливе значення [2].

Аналіз останніх досліджень i публікацій. При збільшенні напрацювання тягового рухомогоскладу із продовженим терміном служби ймовірність появи відмов у несучих конструкціях підвищується [3]. Наприклад, при первинному продовженні призначеного терміну служби електровозів ВЛ80, ЧС2 було встановлено, що ресурс візків буде регламентувати відповідно шворневий брус і кронштейн підвіски кузова. Після 810 років експлуатації в цих елементах почали з'являтися тріщини утоми 3 тенденцією переходу до масового явища. Таке положення спостерігається в несучих конструкціях інших типів рухомого складу [4]. Тому вибір методів та засобів контролю технічного стану рам візків електровозів має особливе значення у зв'язку 3 
незадовільними темпами оновлення тягового рухомого складу.

Мета статті. Проаналізувати стан несучих конструкцій електровозів та методи визначення залишкового ресурсу i запропонувати заходи й технологію контролю технічного стану рам візків електровоза ВЛ8.

Основна частина дослідження. Технічний стан несучих конструкцій iз тривалим напрацюванням 3 погляду ресурсу перейшов на якісно інший рівень, а це у свою чергу потребує і більш досконалого підходу до забезпечення безпеки їх подальшої експлуатації. У цьому зв'язку для конструкцій i3 тривалим напрацюванням розвиток прийнятого підходу полягає в розробленні, прийнятті і реалізації технічних рішень щодо забезпечення необхідної довговічності не тільки по серії рухомого складу в цілому, але й для кожної одиниці індивідуально. При цьому впроваджується поетапний інструментальний контроль технічного стану конструкцій i постійний моніторинг для забезпечення подальшої безпечної експлуатації $[5,6]$.

Як основні показники залишкового ресурсу прийнято розглядати такі [6]:

- середній залишковий ресурс $\pi(t)$, обумовлений як математичне очікування залишкового ресурсу після напрацювання $t$;

- гамма-процентний залишковий ресурс $\pi_{\gamma}(t)$, обумовлений як напрацювання 3 деякого моменту часу $t$, протягом якого об'єкт, що безвідмовно напрацював, буде мати значення умовної ймовірності безвідмовної роботи рівня $\mathrm{y}$ :

$$
\frac{R\left[\tau+\pi_{\gamma}(\tau)\right]}{R(\tau)}=\gamma .
$$

Існують такі методи оцінки залишкового pecyрсу[7, 8]:

- імовірнісний;

- параметричний (на основі магнітної характеристики металу), а також методи, основані на використанні:

- дифузійного розподілу;

- індивідуальних кривих утоми;

- аналізу тимчасовихрядів.

Імовірнісні методи розрахунків ресурсу. На основі дослідження ряду сплавів при різних навантаженнях установлено, що, 3 погляду впливу на довговічність, будь-який процес може бути подано трьома параметрами: математичним очікуванням напруг $\pi_{j}(t)$, щовідбивають статичний зсув процесу навантаження об'єкта (наприклад під дією встановленого вантажу); середнім квадратичним відхиленням напруг, що характеризують інтенсивність динамічного навантаження; параметром структури процесу 3, що інтегрально оцінює імовірнісне співвідношення ординат і максимумів процесу (рис. 1) $[8,9]$.

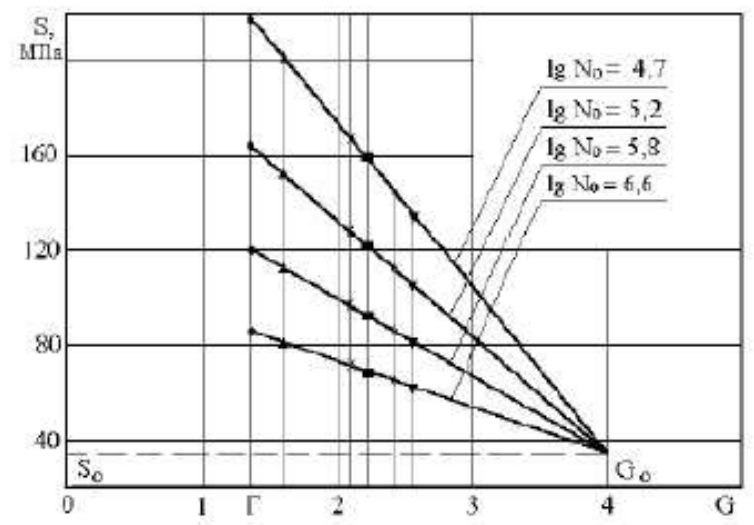

Рис. 1. Узагальнена діаграма характеристик опорівутоми зразків сплаву АМг-61

Параметричні методи очінки поточного стану $i$ залишкового ресурсу металоконструкиій на основі методу неруйнівного контролю. В основу підходу покладений неруйнівний метод поточного контролю (у процесі всього терміну служби) за результатами виміру такої магнітної характеристики металу, як коерцитивна сила $H_{c}$. Такий підхід давно визнаний у металургії й машинобудуванні при здавальномуконтролі готової металопродукції за механічними властивостями.

Крім вихідних положень, також бралося до уваги, що $H_{c}-$ це одна 3 найбільш структурочутливихмагнітних характеристик металу, тому за результатами вимірів $H_{c}$ контролюються механічні властивості не тільки нового металу, але і прослідковується динаміка зміни стану робочого шару в процесі всього терміну служби виробу (рис. 2). 


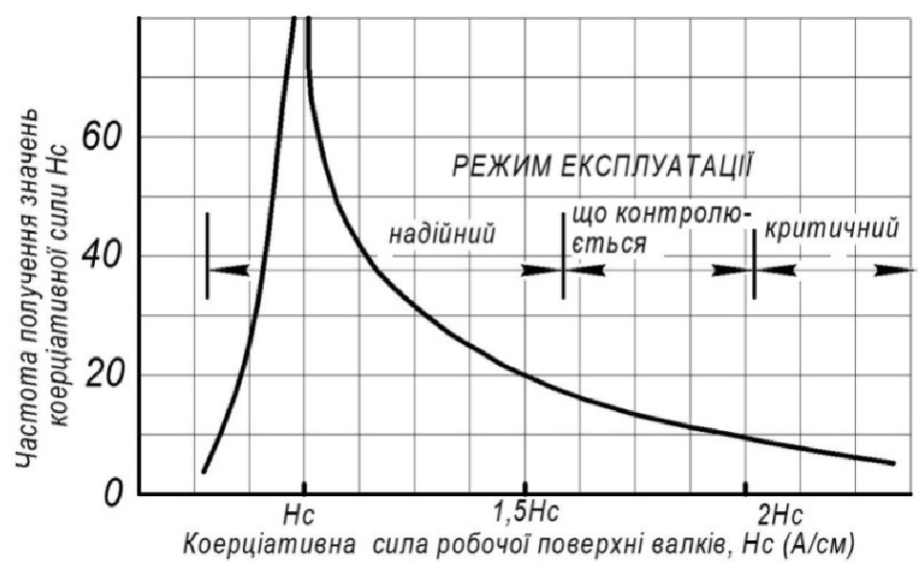

Рис. 2. Генеральний розподіл значень коерцитивної сили на поверхні кочення опорних валків зі сталі 75ХМФ

Нижче при вимірахНс поверхні кочення представницької вибірки 360 шт. прокатних валків протягом їх терміну служби показано, що даний параметр неруйнівного контролю виправдав такі очікування. Усю цю групу валків спостерігали протягом півтора року. При контролі на робочу поверхню валка наносили координатну сітку із прив'язкою іiі до конструкції валка для виконання всіх подальших вимірів у тих самих точках у процесі перевалок. Виміри виконували ручним портативним магнітним структуроскопом КРМЦ-К2М.

Таким чином, при експлуатації коерцитивна силапрямо пов'язана 3 діючими експлуатаційними напругами i нагромадженням пошкоджень у металі, які визначають залишковий ресурс конструкції.

Метод оиінки ресурсу з використанням дифузійного розподілу. Останнім часом усе більше поширення як теоретична модель розподілу відмов механічних виробів одержує дифузійний монотонний розподіл (DMрозподіл).

Якщо відома первісна функція розподілу ресурсу досліджуваних виробів $F(t)$ (або щільність розподілу ресурсу $f(t))$, то можна визначити вираз для характеристик залишкового ресурсу.

Щільність DM-розподілу:

$$
f(t)=\frac{t+\mu}{2 v t \sqrt{2 \pi \mu t}} \cdot \exp \left[-\frac{(t-\mu)^{2}}{2 v^{2} \mu t}\right],
$$

Методи визначення розподілів ресурсу за індивідуальними кривими утоми. Одним 3 можливих способів розрахунків розподілу ресурсу $є$ використання індивідуальних кривих утоми (ІКУ) у вигляді квантилів відповідних значень імовірностей.

Можливі два підходи до побудови ІКУ: прямий і зворотний. Прямий підхід полягає в знаходженні розподілу ресурсу й визначенні дійсної поведінки зразків на основі цих розподілів. Існує й зворотний підхід до моделюванння утомного феномена. Якщо дані розподіли ресурсу, отримані на основі випробувань, необхідно знайти випадкові об'єкти, відповідальні за утомну поведінку зразків.

Моделі залишкового ресурсу 3 використанням методів аналізу тимчасових рядів. Під тимчасовим рядом будемо мати на увазі безліч значень ресурсу, зафіксованих у певний час. Такі ряди дуже часто формуються для контролю технологічного процесу, а також для обліку ресурсних витрат i ряду інших цілей. Моделі, в основі яких лежить використання даних тимчасових рядів (або тимчасових серій), дають змогу одержувати прогнози фіксованих значень у найближчому майбутньому. Побудова таких моделей містить у собі два етапи:

1) аналіз внутрішньої структури даних $\mathrm{i}$ пошук кількісних і якісних тенденцій. Звичайно па цьому етапі відбувається непрямий поділ вихідних даних на систематичний (прогнозований) і випадковий (що не підлягає прогнозу) компоненти; 
2) побудова моделі й прогнозування. Існують два підходи до створення моделей.

Проведений аналіз методів оцінки залишкового ресурсу показав доцільність подальшого вдосконалення методик більш точного виявлення несправностей виробів на ранній стадії експлуатації. Оцінка залишкового ресурсу при використанні таких методик характеризується застосуванням великої кількості багатофакторних залежностей, що виключає розширення бази даних безпосередньо в технологічному процесі. Моделі зношування за своєю суттю є статичними.

Таким чином, актуальними $€$ такі завдання: розроблення нових динамічних моделей, що враховують складні багатофакторні фазові й структурні зміни технічного виробу; створення методик одержання найбільш інформативних ознак виробу з метою подальшого діагностування й оцінювання ймовірності виходу об'єкта з ладу.

В основу підходу визначення залишкового ресурсу покладенийнеруйнівний метод поточного контролю (у процесі всього терміну служби) за результатами виміру такої магнітної характеристики металу, як коерцитивна сила Нc. Такий підхід давно визнаний у металургії й машинобудуванні при здавальномуконтролі готової металопродукції за механічними властивостями.
Першим етапом вирішення поставленого завданняє створення твердотільної моделі (3D) рами візка електровоза ВЛ8.

Модель створена за геометрією складального креслення на раму першого візка ВЛ8.

Рами візків ВЛ8 - суцільнолиті. Їх виготовляли виливанням 3 вуглицевої сталі марки 25 Л-II, до якості лиття ставилися підвищені вимоги. На виготовлення форм потрібні більші витрати праці, однак обсяг механічної обробки суцільнолитих рам дуже малий, а шар кремнезему, що залишається після видалення формувальної землі, зберігає раму від корозії [10].

Товщина стінок балок рами візка 18 мм. Рама має високу міцність, твердість і надійність; однак маса литої рами велика: 56005900 кг в електровоза ВЛ8.

Як матеріал розрахункової моделі рами беремо вуглецеву сталь марки 25 Л-IІ.

Для проведення розрахунків методом конечних елементів система проводить розбивання твердотільної моделі на безліч малих елементарних елементів (тіл), з'єднаних між собою загальними точками - вузлами, тобто генерує сітку конечних елементів, у вузлах якої надалі буде проведений розрахунок напружено-деформованого стану моделі (рис. 3).

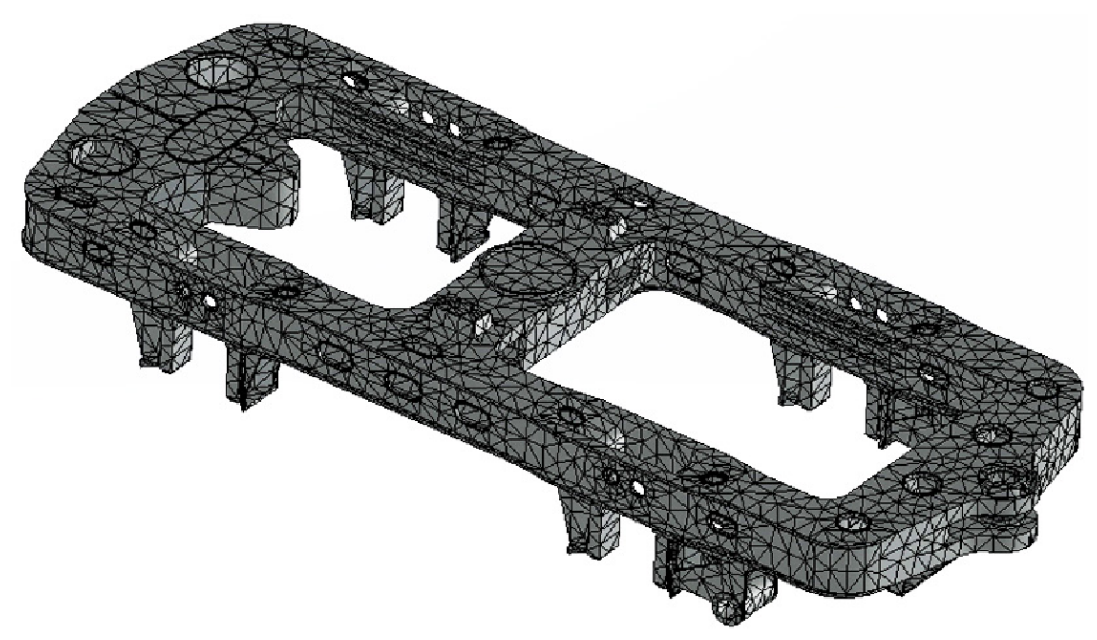

Рис. 3. Сітка конечних елементів на твердотільній моделі рами візка ВЛ8

Процедура розрахунків методом кінцевих елементів моделі рами візка, виконаної в натуральну величину, займає від 2 до 4 хв і залежить від характеристик апаратної частини комп'ютера.
У результаті комплексного розрахунку, проведеного на основі вищезаданих умов навантажень i обмежень, отримані епюра напруженого стану матеріалу рами візка, епюра деформацій у конструкції рами й епюра 
переміщень ділянок рами від впливу прикладених сил.

Результати розрахунків напруженого стану (рис. 4) дають змогу нам визначити місця iз критичними концентраціями напруг у рамі візка, у яких необхідно забезпечити постійний діагностичний контроль у період проведення планових ремонтів.

Як видно 3 результатів розрахунків максимальні напруги при прийнятій схемі закріплень i напруг виникають у місцях кріплення найближчих до шворня рами підвісок. Величина їх у даному розрахунку перевищує межу текучості матеріалу рами візка, що пояснюється прийнятим допущенням про тверде закріплення шворневого вузла. У реальній ситуації сила тяги електровоза, долаючи сили опору поїзда, викликає рух кочення, знімаючи тим самим напруги на рамі.

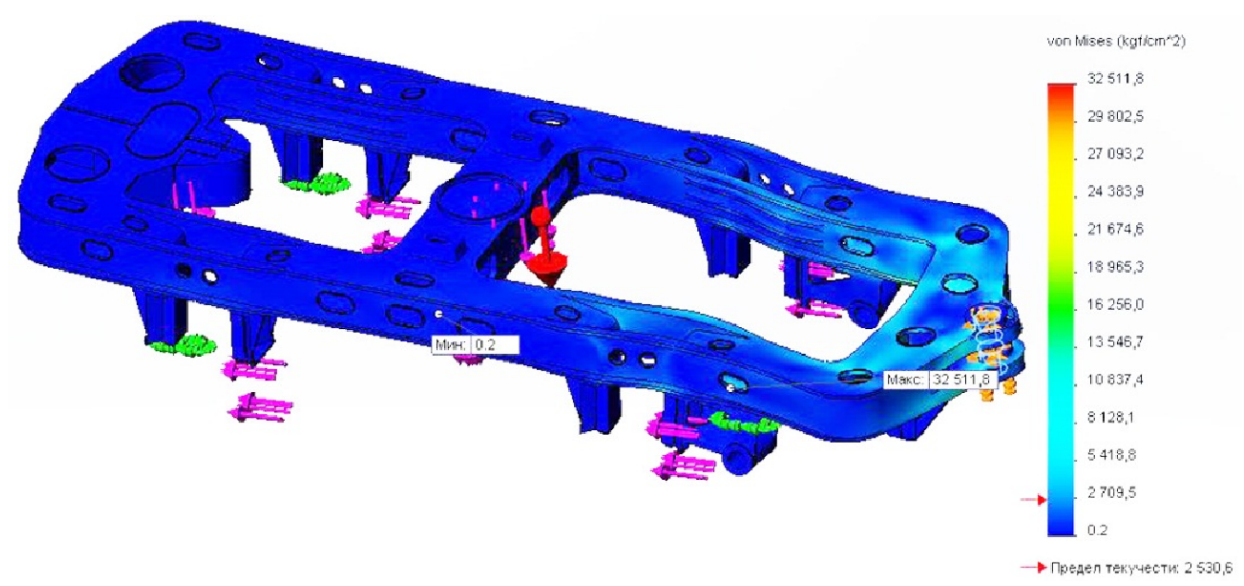

Рис. 4. Епюра напруженого стану рами візка

Таким чином, метод оцінки залишкового ресурсу рам візків складається 3 таких основних етапів:

1) визначення небезпечних елементів на підставі обстеження рами візка iз застосуванням магнітного методу коерцитивної сили й виміром твердості. Проводиться для рам візків, що вперше поміщені на стенд для визначення залишкового ресурсу. Результати широкого обстеження дають змогу:

- скоротити кількість зон конструкції рами, які підлягають постійному контролю;

- визначити початковий рівень коерцитивної сили й твердості в місцях постійного контролю. Обмірювані дані разом 3 історією експлуатації локомотива послужать для формування типової кривої зміни діагностичних параметрів (рівня коерцитивної сили й твердості) від часу експлуатації в умовах даного депо;

- скласти паспорт діагностики на раму візка, де буде фіксуватися динаміка зміни діагностичних параметрів. Це дасть змогу прослідковувати динаміку зміни коерцитивної сили й вчасно вивести раму візка з експлуатації або провести ремонтні заходи в несприятливому вузлі;

2) визначення періодичності постановки рами візка на діагностичний стенд;

3) здійснення вимірів згідно із затвердженою періодичністю. За результатами моніторингу діагностичних параметрів i пов'язаного 3 ним технічного стану вузлів рам (наявність тріщин, утомне викришування часток металу, злами) уточнюється критерій граничного стану рами візка електровозів саме для даного депо.

Своєчасність і оперативність визначення залишкового ресурсу конкретно кожної рами візка можна здійснити при впровадженні в технологічний процес ремонту рам візків ще однієї позиції - діагностичного стенда 3 визначення залишкового ресурсу.

Пропонований стенд являє собою металоконструкцію, на яку поміщають раму візка (рис. 5). Рама стенда обв'язана кронштейнами, на які кріпляться виконавчі органи діагностичних приладів. 


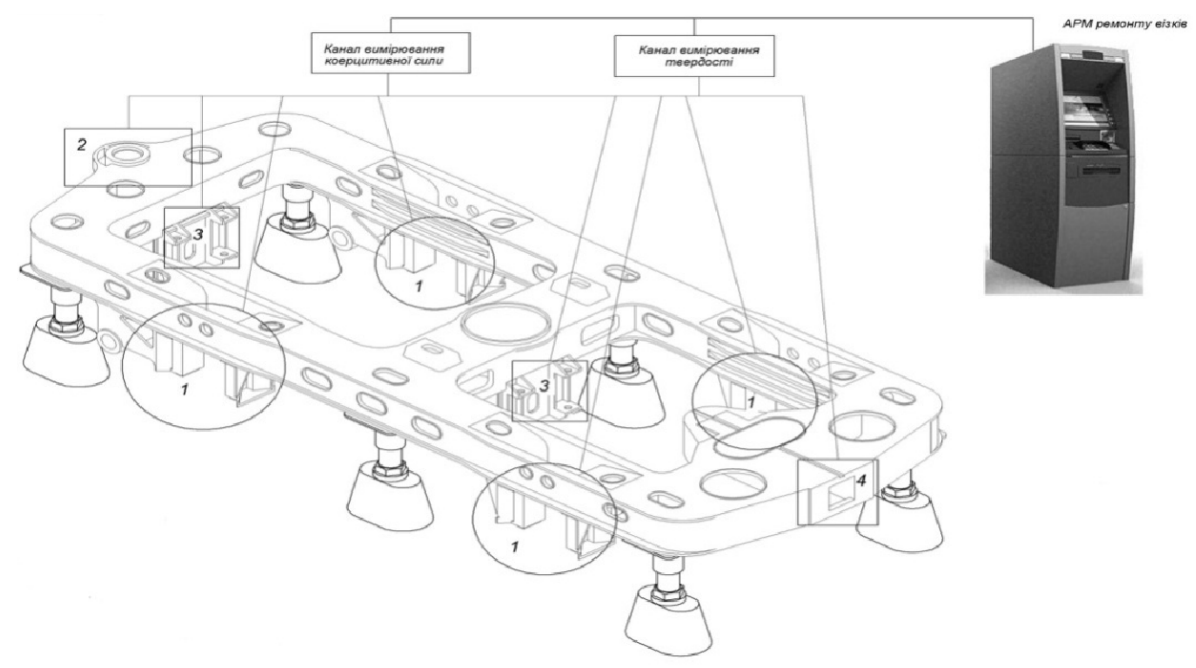

Рис. 5. Схема діагностичного комплексу з визначення залишкового ресурсу рам візків електровозів ВЛ8

Діагностичний комплекс включає: багатоканальний вимірник коерцитивної сили на базі коерциметра Каскад-01, багатоканальний вимірник твердості на базі акустичного твердоміра, пульт керування 3 персональним комп'ютером, що дають змогу управляти послідовністю вимірів, обробляти одержувані результати й передавати їх на АРМ ремонту.

Процес діагностики максимально автоматизований i зводиться до декількох простих операцій. Операторові необхідно попередньо ввести первинну інформацію й по команді 3 пульта «почати вимір» провести автоматичне позиціонування датчиків $\mathrm{i}$ запустити цикл діагностики. Первинні перетворювачі коерциметра й твердоміра, послідовно переміщаючись уздовж щелеп рами, проводять виміри відповідних параметрів i разом iз сигналами 3 первинних перетворювачів, установлених у районі кронштейнів кріплення ТЕД, кутах сполучення балок, передають їх в обробний центр пульта керування, де обчислюються результати вимірів і заносяться у відповідні звіти.

Завдяки цьому цикл діагностики, включаючи підготовчі операції, займає кілька хвилин. Після завершення процесу проводиться автоматична інтерполяція результатів 3 побудовою розподілу коерцитивної сили; визначаються максимальне, мінімальне, середнє значення й інші характеристики. Необхідне програмне й методичне забезпечення входить у комплект поставки.

На підставі отриманих даних може бути зроблений висновок про кількість накопичених у процесі експлуатації дефектів і можливості подальшої експлуатації рами візка.

Висновки. Проведений аналіз методів та засобів визначення залишкового ресурсу рам візків електровозів дає змогу обрати метод прогнозування технічного стану рам візків та робити висновки щодо їх подальшого використання.

\section{Список використаних джерел}

1. Комплекснапрограмаоновленнязалізничногорухомого складу України на 2008 - 2020 роки [Текст] - К.: Укрзалізниця, 2009. - 299 с.

2. Програма енергозбереження на залізничному транспорті [Текст]. - К.: Укрзалізниця, 1997. $30 \mathrm{c}$.

3. Дворецкий, В.И. Оценка остаточного ресурса сварных несущих конструкций и продление срока их службы [Текст] / В.И. Дворецкий // Автоматическая сварка. - 2000. - № 9, 10. - С. 37-42.

4. Повышение долговечности конструкций железнодорожного подвижного состава с длительной наработкой [Текст] / В.И. Дворецкий, Е.Ф. Явдошина, Р.Ю. Дёмин, А.Ю. Черняк // Залізничний транспорт України. - 2010. - № 5. - С. 50-54. 
5. Ремонт электроподвижного состава железнодорожного транспорта [Текст] / В.Я. Алтухов, А.С. Зенкин, В.Г. Кантур, Ф.И. Осадчук. - К.: Техніка, 1983. - 150 с.

6. Находкин, В.М. Ремонт электровозов и электропоездов [Текст] / В.М. Находкин, А.Г Хрисанов. - М.: Транспорт, 1981. - 360 с.

7. Методы оценки показателей надежности по экспериментальным данным. Методические указания [Текст]: РД 50-690-89. - М.: Изд.-во стандартов, 1999. - 56 с.

8. Дубровин, В.И. Методы оценки остаточного ресурса изделий (обзор) [Текст] / В.И. Дубровин, В.А. Клименко // Математичні машини і системи. - 2010. - № 4. - С. 162-167.

9. Стариков, М. Модернизированный метод оценки остаточного ресурса крановых металлоконструкций по параметрам коэрцитивной силы и коэффициента вариации твердости [Текст] / М.А. Стариков, К.А. Никифоров // Вісник інженерної академії України. - 2010. - № 3-4. - С. 196198.

10. Электровоз ВЛ8. Руководство по эксплуатации.[Текст]. - М.: Транспорт, 1982. - 320 с.

Рецензент, д-р техн. наук, професор А.П. Фалендиш

Машкін Олександр Сергійович, слухач ІППК, Український державний університет залізничного транспорту. Тел. (057) 730-10-42.

Mashkin Alexander, listener IPPK, Ukrainian State University of Railway Transport. Tel. (057) 730-10-42.

Наукова праця здана до друку 18.09.2015 р. 